\title{
Cropping Systems to Improve Carbon Sequestration for Mitigation of Climate Change
}

\author{
Qingren Wang ${ }^{1,2}$, Yuncong $\mathrm{Li}^{1,2}$, Ashok Alva ${ }^{3}$ \\ ${ }^{1}$ Tropical Research and Education Center, Homestead, USA; ${ }^{2}$ Department of Soil and Water Science, University of Florida, Gainesville, \\ USA; ${ }^{3}$ USDA, ARS, Vegetable and Forage Crops Research, Prosser, USA. \\ Email: qrwang@ufl.edu
}

Received April 23 ${ }^{\text {rd }}, 2010$; revised May 20 $0^{\text {th }}, 2010$; accepted May $25^{\text {th }}, 2010$.

\begin{abstract}
The recent trend of an increase in the concentration of greenhouse gases $(G H G s)$ in the atmosphere has led to an elevated concern and urgency to adopt measures for carbon (C) sequestration to mitigate the climate change. Among all GHGs, carbon dioxide $\left(\mathrm{CO}_{2}\right)$ is the most important one which occurs in the greatest concentration and has the strongest radiative forcing among all. Reducing the release of $\mathrm{CO}_{2}$ to the atmosphere through "green energy" technologies or fossil fuel energy alternatives, such as wind, solar and hydraulic energies, is a major challenge. However, removal of atmospheric $\mathrm{CO}_{2}$ by terrestrial ecosystems via $C$ sequestration and converting the sequestered $C$ into the soil organic $C$ has provided a great opportunity for shifting GHG emission to mitigate the climate change. Soil is an ideal reservoir for storage of organic $C$ since soil organic $C$ has been depleted due to land misuse and inappropriate management through the long history. To optimize the efficiency of $C$ sequestration in agriculture, cropping systems, such as crop rotation, intercropping, cover cropping, etc., play a critical role by influencing optimal yield, total increased C sequestered with biomass, and that remained in the soil. As matter of fact, soil C sequestration is a multiple purpose strategy. It restores degraded soils, enhances the land productivity, improves the diversity, protects the environment and reduces the enrichment of atmospheric $\mathrm{CO}_{2}$, hence shifts emission of GHGs and mitigates climate change.
\end{abstract}

Keywords: Carbon Dioxide, Carbon Sequestration, Climate Change, Cropping System, Greenhouse Gas

\section{Introduction}

Rapid increase in carbon dioxide $\left(\mathrm{CO}_{2}\right)$ concentration in the atmosphere associated with other greenhouse gases (GHGs), such as nitrous oxide $\left(\mathrm{N}_{2} \mathrm{O}\right)$ and methane $\left(\mathrm{CH}_{4}\right)$, since the industrial revolution is a major concern with respect to its impact on climate change. Therefore, there is an urgency to adopt effective measures for mitigating the threat of global climate change [1]. The concentration of $\mathrm{CO}_{2}$ in the atmosphere increased from 280 to 387 ppmv in 1750 to 2007, and continues to increase at the rate of 1.5 ppmv per year. During the same period, $\mathrm{N}_{2} \mathrm{O}$ was increased from 270 to $314 \mathrm{ppbv}$, and $\mathrm{CH}_{4}$ increased from 700 to 1745 ppbv (Table 1) [2,3]. Increased concentration of GHGs impacts the temperature of the Earth by absorbing and emitting radiation within the thermal infrared range. The anthropogenic enrichment of GHGs in the atmosphere and the cumulative radiative forcing (factors affect the balance between incoming solar radiation and outgoing infrared radiation within the Earth's atmosphere) has led to a substantial increase in global surface temperature. The major sources to enrich the atmospheric GHGs are fossil fuel combustion and land use changes. For instance, about $25 \%$ of $\mathrm{CO}_{2}, 50 \%$ of $\mathrm{CH}_{4}$ and up to $70 \%$ of $\mathrm{N}_{2} \mathrm{O}$ released globally through human sources [4]. Increased frequency of natural disasters, such as floods, tsunami, hurricane, etc., during the recent years might be attributed to the climate change associated to increased accumulation of GHGs in the atmosphere. The global surface temperature increased by $0.6^{\circ} \mathrm{C}$ since the late $19^{\text {th }}$ century with a current average warming rate of $0.17^{\circ} \mathrm{C}$ per decade [2]. Such temperature increase would considerably alter the distribution of precipitation, e.g., $0.5-1 \%$ of precipitation increase per decade in the most of Northern Hemisphere and $0.3 \%$ increase in the tropics and sub-tropics [1]. Consequently, land productivity, biomass accumulation, biodiversity, and the whole environmental system would be negatively impacted. The US EPA has released its final findings on greenhouse gases and has declared that "GHGs threaten 
the public health and welfare of the American people" [5]. Therefore, it is urgent to adopt practical and effective approaches to controlling the GHG emission for mitigating global climate change for a sustainable development of the environment. The objective of this review is to briefly elucidate the main sources of GHG emission and particularly address the sustainable development of cropping systems for carbon sequestration to mitigate the threat of the global climate change.

\section{Major Sources of GHGs and their Contributions}

A major source of $\mathrm{CO}_{2}$ in the atmosphere is fossil fuel combustion and cement production. Total emission from the above source increased from $5.4 \pm 0.3$ to $7.9 \mathrm{Pg} \mathrm{C}$ $\mathrm{yr}^{-1}$ in the global scale in $1980 \mathrm{~s} ; 6.3 \pm 0.4 \mathrm{Pg} \mathrm{C} \mathrm{yr}^{-1}$ from the same source in the 1990s; and up to 7.9 $\mathrm{Pg} \mathrm{C} \mathrm{yr}^{-1}$ from 1980 to $2005[1,6]$. Over $70 \%$ of the total emission is from combustion of liquid and solid fuels. Land use change, such as deforestation, land degradation, etc. also contribute to anthropogenic $\mathrm{CO}_{2}$ emission $[1,7,8]$, which has been constant at about $1.7 \pm 0.8 \mathrm{Pg} \mathrm{C} \mathrm{yr}^{-1}$ during 1980s through 2005. The global emission of carbon is estimated at $270 \pm 30 \mathrm{Pg}$ due to fossil fuel combustion and $136 \pm 55 \mathrm{Pg}$ due to land use change and soil cultivation during the last 150 years [1,9-11]. The $\mathrm{CO}_{2}$ emission rate has increased dramatically since 2000 , as evident from an increase from 1.1\% during 1990-1999, to $>3 \%$ since 2000. This is attributed to increased energy demand with an increase in gross domestic product (GDP) [6].

Besides $\mathrm{CO}_{2}$, there are some other gases that can contribute the global climate change. However, the contribution to the greenhouse effect by different gases is determined by the characteristics of the gas and its abundance. For instance, $\mathrm{CH}_{4}$ is about 8 fold stronger than $\mathrm{CO}_{2}$ on a molecule-for-molecule basis, however the net contribution of $\mathrm{CH}_{4}$ to the greenhouse effect is much smaller because its lower concentration than that of $\mathrm{CO}_{2}$. From the radiative forcing of the main GHGs, $\mathrm{CO}_{2}, \mathrm{CH}_{4}$ and $\mathrm{N}_{2} \mathrm{O}$ (Table 1), it is also evident that $\mathrm{CO}_{2}$ is the predominant GHG. Similarly, the other three GHGs named in the
Kyoto Protocol, hydrofluorocarbons, perfluorocarbons, and sulfur hexafluoride (US EPA, 2009) may impact the climate change but their radiative forcing is considerably low due to their very low concentrations as compared to that of $\mathrm{CO}_{2}$. Therefore, it is important to control the concentration of atmospheric $\mathrm{CO}_{2}$ by reducing its emission by using fossil fuel more efficiently than ever before, and by adoption of "green-energy technologies", such as fossil fuel alternatives, solar, wind, hydraulic energies, etc. On the other hand, terrestrial plants play a critical role to remove the atmospheric $\mathrm{CO}_{2}$ via their photosynthesis and assimilation of $\mathrm{CO}_{2}$ to produce plant biomass.

\section{Carbon Sequestration for Shifting GHG Mitigation}

Carbon sequestration by terrestrial vegetation, as one of the most effective options for shifting the GHG emission has been identified by the Intergovernmental Panel on Climate Change [2]. Terrestrial ecosystems associated with land use and soil management play an important role in the global $\mathrm{C}$ budget [1]. For example, the current terrestrial sink for carbon is estimated to hold $550-700 \mathrm{Pg}$ of carbon in the world's vegetation and 1200-1600 Pg of soil organic carbon [8]. This has shown a great potential to offset the total amount of $\mathrm{C}$ emitted and accumulated in the atmosphere through all possible sources.

Therefore, the United Nations (UN) Framework Convention on Climate Change (UNFCC) has setup 3 major conventions to combat desertification, land degradation, and improving biodiversity. Furthermore, the Kyoto Protocol, negotiated in 1997, provides the framework for activities aimed at reducing emissions of GHGs. The protocol contains a joint commitment of the industrialized countries to reduce their GHG emissions by at least $5 \%$ below the levels of 1990 , over the period of 2008 2012 [12].

The removal of atmospheric $\mathrm{CO}_{2}$ by increasing the assimilation of $\mathrm{CO}_{2}$ with terrestrial vegetation, retaining $\mathrm{C}$ and enhancing the transformation of atmospheric $\mathrm{C}$ to plant biomass and soil organic matter along with reducing GHG emission has become a worldwide strategy to

Table 1. Increase of dominant greenhouse gases and their radiative forcing [3].

\begin{tabular}{|c|c|c|c|c|c|}
\hline Greenhouse gases & Preindustrial level & Current level & \multicolumn{2}{|c|}{ Increase } & $\begin{array}{l}\text { Radiative forcing } \\
\qquad\left(W / \mathbf{m}^{2}\right)\end{array}$ \\
\hline $\mathrm{CO}_{2}$ & $280 \mathrm{ppmv}$ & $387 \mathrm{ppmv}$ & $107 \mathrm{ppmv}$ & $38 \%$ & 1.46 \\
\hline $\mathrm{CH}_{4}$ & 700 ppbv & $1745 \mathrm{ppbv}$ & $1045 \mathrm{ppbv}$ & $149 \%$ & 0.48 \\
\hline $\mathbf{N}_{2} \mathrm{O}$ & $270 \mathrm{ppbv}$ & 314 ppbv & $44 \mathrm{ppbv}$ & $16 \%$ & 0.15 \\
\hline CFC-12* & 0 & 533 pptv & 533 pptv & - & 0.17 \\
\hline
\end{tabular}

*CFC: chlorofluorocarbon 
mitigate climate change. However, the efficiency of $\mathrm{C}$ sequestration by various vegetations and management in various systems differs greatly due to their physiological characteristics, growth rates, biomass accumulation, and environmental factors. Therefore, it is important to optimize ecosystems based on various climates and geographical characteristics to efficiently and effectively sequester $\mathrm{C}$ from the atmosphere and for shifting the mitigation of the climate change.

Regarding the $\mathrm{C}$ source and sink in the global ecosystems, there have been a lot of controversial arguments. Forest is commonly considered as a $\mathrm{C}$ sink because the storage of organic $\mathrm{C}$ accumulated in trunks and major branches of a tree can last longer and the $\mathrm{C}$ cycling is slower than that in annual plants. However, it is only a "time" issue because the C slowly sequestered in forests through a long term period might be easily returned to the atmosphere either through deforestation or through climate-change induced emissions. As indicated by Turner et al. [13], significant losses of $\mathrm{C}$ are associated with harvesting either for biomass energy or for wood products even for intensely managed forests. In the case of biomass energy, $\mathrm{C}$ is lost in one-way emission as a source through direct fuel combustion of wood. For wood products, only about $23 \%$ of merchantable wood can be harvested [14] and noncommercial parts of the tree are burned as slash or left to decompose. Also, a large fraction of the merchantable wood may become products with lifetimes of less than 5 years [13]. Wildfires, often occurs in forest, can cause an abrupt emission of $\mathrm{CO}_{2}$ to the atmosphere. In addition, prevailing afforestation projects may often not be desirable from a social point of view and it might compete for land use with food production in agriculture to meet people's need as population grows. Afforestation may not be desirable either from the point of view in improving the biodiversity. Nevertheless, the Kyoto Protocol, in its original form focuses on forestry activities, such as afforestation and management, to improve the $\mathrm{C}$ sink. However, there may be a number of problems difficult to be solved for what are related to such forestry activities, particularly monitoring and verification, permanence, leakage and environmental effects in $\mathrm{C}$ sequestration by forest. In addition, safeguarding $\mathrm{C}$ stored in aboveground biomass of forests is difficult due to economic pressure that encourages logging for income returns, which definitely stimulates litter decomposition and $\mathrm{CO}_{2}$ release.

\section{Potential and Prospects of Cropping Systems for C Sequestration}

\subsection{Soil Organic C Stock for C Sequestration}

There are advantages in promotion of degraded agro-eco- systems as a potential C sink because agriculture occupies a larger portion of global land area (about 35\%) than any other land use (Table 2). Soil organic C (SOC) in cultivated soils, where it contributes to soil fertility, might be less tempting to release through overexploitation due to slow decomposition. As matter of fact the prospects of good crop yields in the future would be jeopardized if the soil fertility cannot be maintained properly [12]. However, in agro-ecosystems that account a main proportion of the whole ecosystems, soil fertility is an important contribution to improve the biomass production and as in turn, increases the SOC accumulation by various vegetations. However, the conversion of the plant sequestered $\mathrm{C}$ to soil organic $\mathrm{C}$, which forms recalcitrant $\mathrm{C}$, plays a crucial role since the soil $\mathrm{C}$ can have a very stable and long residence time, hundreds and even thousands of years under most circumstances [15].

Agricultural soils under appropriate management can contain substantial amounts of soil $\mathrm{C}$ in the form of soil organic matter (SOM). Soils, excluding carbonated rocks, constitute the largest carbon pool, approximately $1500 \mathrm{Gt}$, which is almost three fold greater than that stored in the terrestrial biomass and twice the amount stored in the atmosphere [16]. The SOM contributes to plant available nutrients, buffers environmental stress, improve water-holding capacity, and reduce erosion. In addition, agricultural soils possess potential to restore a considerable quantity of sequestered $\mathrm{C}$ since a significant amount of SOC has been lost from the system due to land degradation and mismanagement. Most croplands have lost 30-40 Mg C ha ${ }^{-1}$, and most degraded soils may have lost 40-60 Mg C ha ${ }^{-1}$ [17]. Restoration of such quantity of soil $\mathrm{C}$ via $\mathrm{C}$ sequestration in agro-ecosystems can, apart from removing $\mathrm{CO}_{2}$ from the atmosphere, improve the sustainable production of the agriculture. In addition, compared to $\mathrm{C}$ passively stored in a forest, the SOC in agricultural soils can actively benefit food production and improve the agricultural sustainability. However, the historical $\mathrm{C}$ loss from the soil cannot be ignored since

Table 2. Total area of land uses and their distributions worldwide (adopted from FAO, 2001).

\begin{tabular}{ccc}
\hline Land use & Area (Mha) & $\mathbf{\%}$ \\
\hline Permanent crops & 132 & 0.9 \\
Arable land & $\mathbf{1 , 3 6 9}$ & $\mathbf{9 . 7}$ \\
Permanent pasture & 3,460 & 24.5 \\
Forest and woodland & 4,172 & 29.6 \\
Agricultural land & 4,961 & 35.2 \\
Total land area & 14,094 & 100.0 \\
\hline
\end{tabular}


about $20 \%$ of the anthropogenic emissions of $\mathrm{CO}_{2}$ was contributed by agriculture and land-use change [18]. Much of the historic C loss (about 66-90 Pg C) from the soil can be restored via $\mathrm{C}$ sequestration in 25-50 years [1] with appropriate land management. Indeed, soil has possessed a promising potential for $\mathrm{C}$ sequestration and $\mathrm{C}$ storage. A summary of soil $\mathrm{C}$ sequestration rates in the crop land of major countries is listed in Table 3, which shows that the cropland can sequester about 75-208 Tg C $\mathrm{yr}^{-1}$ in US, $24 \mathrm{Tg} \mathrm{C} \mathrm{yr}^{-1}$ in Canada, 90-120 $\mathrm{Tg} \mathrm{C}^{-1}{ }^{-1}$ in the European Union, 105-198 $\mathrm{Tg} \mathrm{C} \mathrm{yr}^{-1}$ in China and

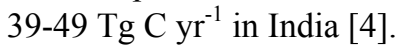

\subsection{Cropping Systems for C Sequestration}

The great potential of $\mathrm{C}$ sequestration in cropland has provided a promising approach to reducing the atmospheric concentration of $\mathrm{CO}_{2}$ for mitigating climate change. However, this approach depends on cropping systems, which may be defined as an operating system for growers to follow in their practices for crop production. An ideal cropping system for $\mathrm{C}$ sequestration should produce and remain the abundant quantity of biomass or organic $\mathrm{C}$ in the soil.

The organic $\mathrm{C}$ concentration in the surface soil (0-15 $\mathrm{cm}$ ) largely depends on the total input of crop residues remaining on the surface or incorporated into the soil. It decreases soil $\mathrm{C}$ greatly to remove crop top from the soil by cleaning up the land [19]. Therefore, to improve $C$ sequestration, it is critical to increase the input of plant biomass residues. Biomass accumulation can be enhanced by an increase in cultivation intensity, growing cover crops between main crop growing seasons, reducing fallow period of land, crop rotations, and intercropping systems. Biomass return to the soil can be improved by elimination of summer or winter fallow, and maintaining a dense vegetation cover on the soil surface, which can also prevent soil from erosion for SOC loss. The major strategies in developing cropping systems are discussed below.

Table 3. Potential of soil $C$ sequestration in cropland of major countries [4].

\begin{tabular}{|c|c|}
\hline Country (region) & $\begin{array}{l}\text { Potential rate of } C \text { sequestration } \\
\text { in cropland }\left(\mathrm{Tg} C \mathrm{yr}^{-1}\right)\end{array}$ \\
\hline U.S.A. & $75-208$ \\
\hline China & $105-198$ \\
\hline European Union & $90-120$ \\
\hline India & $39-49$ \\
\hline Canada & 24 \\
\hline
\end{tabular}

\subsubsection{Crop Rotation}

Crop rotation can improve biomass production and soil C sequestration, especially rotations with legumes and non-legumes. Growing legumes can substantially reduce the nitrogen input as chemical fertilizers, which in turn can reduce the fossil fuel consumption in manufacturing fertilizers [20,21]. Conversely, without appropriate crop rotation, soil productivity and biomass production will decrease due to an infestation increase in weeds, diseases, and insects. Increase in cropping intensity or cropping more frequently by reducing the frequency of bare land fallow in the crop rotation is another effective approach to improve biomass production and soil $\mathrm{C}$ sequestration. In addition, increase cropping intensity can decrease organic matter decomposition rate and mineralization/oxidation of SOC [22]. A long term (15 yrs) study with corn and soybean cropping systems indicated that the corn-soybean rotation system had the greatest productivity and returned the largest crop residues to the soil compared to monoculture of corn or soybean [23]. The above study implies that application of low carbon-tonitrogen residues to maintain soil fertility in the major corn-soybean growing region in the U.S. would increase soil $\mathrm{C}$ sequestration by $13-30 \mathrm{Tg}^{-1} \mathrm{rr}^{-1}$. This is equal to $1-2 \%$ of the estimated annual $\mathrm{C}$ released into the atmosphere from fossil fuel combustion in the U.S. (1.4 Pg C $\left.\mathrm{yr}^{-1}\right)$ [24].

\subsubsection{Intercropping}

Intercropping can improve the crop productivity due to increased efficiency of utilization of sunlight with an adequate spatial distribution of various plant architectures. Intercropping systems include row intercropping, strip intercropping, mixed cropping and relay intercropping, which depends mainly on the characteristics of various crops in spatial distribution and cropping goals. For example, row intercropping corn or sorghum with vine crops, such as climbing beans or sweet potato, can improve the productivity of the latter crop since their vines can climb on the former plants to take the advantage of space and sunlight. In which, the former plants usually may be expected to produce optimal yield because of their sacrifices to support the latter plants. For the convenience of harvests for different crops, especially applying combined harvest machines, strip cropping is preferred. Selecting crops or varieties with various maturity dates may help staggered harvest. In India, the sorghum and pigeonpea intercropping is a common practice. In this intercropping system, sorghum dominates the early stage of growth and mature in about 4 months, and the slow-growing pigeonpea flowers and ripen after the harvest of sorghum, which efficiently utilize the time and space for an optimal productivity of both 
crops [25].

Intercropping can improve the crop productivity considerably. For example, based on the land equivalency ratio $($ LER $)[$ LER $=($ intercropping crop $1 /$ pure crop 1$)+$ (intercropping crop 2/pure crop 2)], the total yields of sweet corn and southern peas with intercropping systems at different densities showed that $30-48 \%$ more land is required to produce the same yield (Table 4) in south Carolina [26].

There are many examples applying intercropping system to improve total crop yields and incomes. For instance, in Iowa, a strip cropping system with oats, corn and soybean on ridge-till rows showed that net returns with strip intercropping can be increased by 38\% ( $\$ 188$ vs. $\$ 136 \mathrm{ha}^{-1}$ ) compared with same crops in monoculture [27]. Another example is that intercropping oat, corn and soybean increased oat yield by $5 \%$, corn yield by $12-15 \%$, soybean yields dropped by $10 \%$ on the border rows due to the shading impact but the yield in the middle rows were much higher than that at the border to offset such a yield loss. As a result, the total soybean yield in this system was greater than that in the monoculture [28]. The total yield increase and benefit improvement from such intercropping system can be attributed to mutual benefits or synergetic effects of various crops. For instance, in the above intercropping system, the early-maturing oats efficiently utilized sunlight, soil nutrients and water to produce yields before corn fully developed to create shading and competition impacts on water and nutrients, and the corn strips can provide wind protection for oats. Soybean can fix nitrogen by rhizobium bacteria to supplement compensation of nutrient uptake by corn, and corn strips can provide an effective windbreak to protect soybean. In addition, strip intercropping can efficiently reduce the infestation by insects and pathogens of the host plants. In Yunnan province of China, the blast disease of rice was

Table 4. Yields of sweet corn and southern peas with intercropping at different densities [26].

\begin{tabular}{cccc}
\hline Plant density* & $\begin{array}{c}\text { Corn yield } \\
\left(\mathbf{M g ~ h a}^{-1}\right)\end{array}$ & $\begin{array}{c}\text { Peas (Mg } \\
\left.\mathbf{h a}^{-1}\right)\end{array}$ & $\begin{array}{c}\text { Land } \\
\text { equivalency } \\
\text { requirement } \\
\text { (LER) }\end{array}$ \\
\hline Full corn & 6,272 & - & - \\
Full peas & - & 1,344 & - \\
Low corn & 4,704 & 896 & 1.41 \\
Medium corn & 5,152 & 896 & 1.48 \\
High corn & 5,600 & 560 & 1.30 \\
\hline
\end{tabular}

*low corn: 2,714 plants ha ${ }^{-1}$; medium corn: 3,848 plants ha ${ }^{-1}$; high corn: 4,820 plants ha $^{-1}$; and peas were 12,879 plants ha $^{-1}$ in all intercropping plots. successfully controlled by adopting a mixture of two different rice varieties instead of a typical pure stand of a single variety. This in turn decreased the need for chemical fungicides [29].

Mixed cropping is also an effective approach in the intercropping system to optimize the ecosystem for maximum plant production by planting two or more plants in a mixture. The benefits of mixed cropping are to balance the input and output of soil nutrients, suppress weeds and insects, control plant disease, resist climate extremes, such as wet, dry, hot and cold, and to increase the overall productivity with limited resources [30]. The classic example of mixed cropping is that the American "three sisters", corn, beans and curcurbits (squash and pumpkins). These plants, domesticated at different times, were together an important component of Native American agriculture. In the history, all these three plants were seeded in the same hole. The corn provides a stalk for the beans to climb on, the beans are nutrient-rich to offset what taken up by corn, and the squash or pumpkin grows low to the ground to keep weeds down and to prevent water from evaporation. With these mutual benefits, an overall optimal productivity with corresponding quantity of biomass of both underground and aboveground can be reached, which shows a potential for biomass return and soil $\mathrm{C}$ sequestration.

In the modern agriculture, such mixed cropping system has to be modified for the convenience of management and harvest with machinery. In addition to grazing pastures, there are a number of successful selections for the mixed cropping system in agriculture, such as wheat and chickpea; soybean and pigeon pea; peanut and sunflower; sorghum and pigeon pea; barley and chickpea; wheat and mustard; and cotton and peanut, etc. [31]. Furthermore, mixed cropping has a long history and it has been practiced in India, China and many other countries. For instance, Horrocks et al. [32] revealed the mixed cropping system in early New Zealand; Jahansooz et al. [33] reported the yield increase of wheat and chickpea in mixed cropping compared with sole cultivation in Australia; Gunes et al. [34] demonstrated the mutual benefits in mineral nutrients and soil moisture by mixed cropping in Europe; and Sahile et al. [35] showed that mixed cropping can promote proactive integrated disease management because mixed cropping of faba bean with cereals (barley and corn) can contribute to the slowing of chocolate spot epidemics and increase grain yield of faba bean in Ethiopia.

Relay intercropping, such as planting soybean into standing winter wheat between 20 and 30 days prior to wheat harvest, can efficiently take spatial and time advantages for optimal yield and eliminate the fallow period to conserve the soil and reduce water evaporation. 
The key to succeed in relay intercropping is timing and wheat row spacing for both plants to develop. If soybean is planted too early, it will become very tall and spindly due to lack of sufficient sunlight, and too late will delay the soybean development, and the spacing of 25 to $38 \mathrm{~cm}$ in wheat row of width is appropriate at Ohio State [36]. Too narrow wheat row spacing will limit the development of soybean plants and too wide will sacrifice the wheat yield. Since the relay intercropping can capture and utilize as much sunlight as possible, it has profound effect on the growth of intercropped soybean. Such a cropping system increases the net return and overcomes the risk of over production of one commodity and price fluctuations. Meanwhile, the land can be well covered and natural resources, especially the sunlight and soil, are efficiently utilized to produce economic yield and improve biomass accumulation.

\subsubsection{Cover Cropping}

Growing cover crops is another effective approach to improve $\mathrm{C}$ sequestration and SOC storage. In the temperate region, winter cover crops, such as rye, ryegrass, oats, pea, vetch, clover, are commonly grown in fall, survived through the mild winter and grow again in spring to cover the bare lands during the off season. The biomass production of vetch and rye winter cover crops in biculture often ranges 5.7 to $8.2 \mathrm{Mg} \mathrm{ha}^{-1}$ in the aboveground, and 372 to $880 \mathrm{~kg} \mathrm{ha}^{-1}$ belowground, which result in a total C input to the soil ranged from 6.8 to 22.8 $\mathrm{Mg} \mathrm{ha}^{-1}$ by cover crops, cotton and sorghum in rotation [37]. Sainju et al. [37] also reported that SOC increased by $6-8 \%$ with cover crops at 0 to $10 \mathrm{~cm}$, and by $0.4 \%$ with rye in monoculture and 3\% with vetch and rye in biculture at $0-30 \mathrm{~cm}$. However, in the tropical or subtropical region, summer cover crops, such as sunn hemp, velvetbean, sorghum sudangrass, are prevailing species grown during the hot and humid summer to cover the bare land conserving soil and water and those summer cover crops, especially sunn hemp can produce as much as $15 \mathrm{Mg} \mathrm{ha}^{-1}$ of aboveground biomass and $3.5 \mathrm{Mg} \mathrm{ha}^{-1}$ belowground biomass, combined contributes to $8 \mathrm{Mg} \mathrm{ha}^{-1}$ of organic C input into the soil within 3 months $[38,39]$. Therefore, cover cropping system provides an excellent strategy to improve $\mathrm{C}$ sequestration for mitigation of climate change.

\subsubsection{Companion Cropping}

In organic farming for vegetable production system, companion cropping system is often practiced. For example, the use of permanent beds of companion crop grown alongside the vegetable crops (e.g., lettuce, cabbage, etc.) has been developed under various conditions, which is perceived as a possible alternative in organic crop production. Companion crops also have the poten- tial to reduce the impact of pests and weeds to benefit the vegetable crops because of the biodiversity. However, the vegetable crop may benefit from the companion crop through a number of channels [40], for example:

Trapping effects: an excellent example is the use of collards to attract the diamondback moth (Plutella xylostella) away from cabbage because the former plant is more attractive to the pests [41].

Biochemical pest suppression: Some plants exude chemicals from roots or aerial parts that can suppress or repel pests and protect the neighboring plants. For instance, the African marigold (Tagetes erecta), which can release thiopene, a nematode repellent, making it a good companion for a number of garden crops. Allelochemicals, such as juglone found in black walnut, can suppress the growth of many plants, which can be used for weed control. The use of mown-killed grain rye as a mulch can prevent weed germination but do not affect transplanted tomatoes, broccoli, or many other vegetables.

Nursing effects: Tall and dense-canopied plants may protect more vulnerable species through necessary shading (e.g., ginger plant) or by providing windbreak. For instance, oats have been long used to help the establishment of alfalfa and other forages. In some cases, the nurse effect can act simply as a physical-spatial interaction function to benefit the main crop.

\subsubsection{Ratoon Cropping}

Ratoon cropping is a technique allowing a crop to produce two or more harvests for yield from one planting. The basic requirements in ratoon cropping are that the crop has to have a well developed root system, earlier maturity and a perennial nature. Ratoon cropping has obvious advantages for crop production and soil $\mathrm{C}$ sequestration. For instance, ratoon cropping reduces the cost of production via savings in land preparation and planting; it has a better use of the growing season; efficiently utilize the sunlight energy; higher yields and biomass per unit area can be reached in a given period of time; less use of irrigation water and fertilizer than the main or original crop because of a shorter growth period; prevent soil and water erosion and nutrient leaching; and more productive economically compared to conventional cropping system. Ratooning sorghum [Sorghum bicolor (L.) Moench] or sugarcane (Saccharum officinarum L.) is successful [42], and the main crop should be cut at about $2.5-10 \mathrm{~cm}$ above the ground level after its maturity. Okra (Abelmoschus esculentus) is another ideal ratooning vegetable crop in tropics or subtropics, for which such ratooning can be conducted two or three times [43].

\subsubsection{Cropping Practices}

Appropriate cropping practices, such as fertilization to adjust nutrient balance, appropriate water supply, etc., 
are important factors to optimize biomass production, improve crop growth and development. However, conventional tillage, especially the moldboard plowing, can result in rapid mineralization of SOC, which leads to SOC depletion rather than sequestration. Therefore, to enhance $\mathrm{C}$ sequestration in the soil, increased amount of plant residues must be returned to the soil and the soil must be kept a minimum disturbance. In addition, it is important to transfer the sequestered $\mathrm{C}$ into a physically or chemically stable form, such as recalcitrant $\mathrm{C}$ or soil organic $\mathrm{C}$ via slow humification or carbonization process.

The stability of organic $\mathrm{C}$ in plant residues or in soil pool depends largely on environmental changes, such as soil types, temperature, and moisture. However, the plant components play a major role for its organic $\mathrm{C}$ stability against its decomposition rate. For example, usually there are two major compartments of organic $\mathrm{C}$ in plants, active and inert, which might refer to labile and recalcitrant pools, respectively, in two-pool models proposed by McLauchlan and Hobbie [44]. The active organic C consists of 4 sub-components, decomposable organic $\mathrm{C}$, resistant organic $\mathrm{C}$, microbial biomass organic $\mathrm{C}$, and humified organic $C$ [45]. The physiological and chemical characteristics in plant residues, such as $\mathrm{C}: \mathrm{N}$ ratio and lignin content, may affect the distribution of those different organic C compartments, which consequently influence the decomposition rates. There are a number of reports on $\mathrm{C}$ sequestration or SOC accumulation in croplands through integrated cropping systems and cropping practices, such as conservation tillage; cover cropping, crop rotation; land use restoration or shifting cultivation, and fertilization, etc. [4,16,19,37,46-49]. Obviously, soil organic $\mathrm{C}$ pool has a great potential to store sequestered $\mathrm{C}$ and integrated cropping systems associated with cropping practices has displayed the promising prospects in $\mathrm{C}$ sequestration from the atmosphere and shifting the mitigation of climate change.

\section{Acknowledgements}

The research was financially supported via a USDA-ARS collaboration research program.

\section{REFERENCES}

[1] R. Lal, "Soil Carbon Sequestration to Mitigate Climate Change," Geoderma, Vol. 123, No. 1-2, 2004, pp. 1-22.

[2] IPCC, "Climate Change 2001: The Scientific Basis," Intergovernmental Panel on Climate Change, Cambridge University Press, Cambridge, 2001.

[3] IPCC, “Assessment Report,” 2007. http://www.ipcc.ch/pdf/ assessment-report/ar4/syr/ar4_syr_spm.pdf

[4] J. J. Hutchinson, C. A. Campbell and R. L. Desjardins,
"Some Perspectives on Carbon Sequestration in Agriculture," Agricultural and Forest Meteorology, Vol. 142, No. 2-4, 2007, pp. 288-302.

[5] U.S. EPA, "Greenhouse Gases Threaten Public Health and the Environment/Science Overwhelmingly Shows Greenhouse Gas Concentrations at Unprecedented Levels Due to Human Activity," 2009. http://yosemite.epa.gov/ opa/admpress.nsf/d0cf6618525a9efb85257359003fb69d/ 08d11a451131bca585257685005bf252! OpenDocument

[6] M. R. Raupach, G. Marland, P. Ciais, C. L. Quéré, J. G. Canadell, G. Klepper and C. B. Field, "Global and Regional Drivers of Accelerating $\mathrm{CO}_{2}$ Emissions," Proceedings of the National Academy of Sciences USA, Vol. 104, No. 24, 2007, pp. 10288-10293.

[7] R. A. Houghton and D. L. Skole, "Carbon," In: B. L. Turner, II, W. C. Clark, R. W. Kates, J. F. Richards, J. T. Mathews and W. B. Meyer, Eds., The Earth as Transformed by Human Action, Cambridge University Press, Cambridge, 1990.

[8] K. Paustian, O. Andrén, H. H. Janzen, R. Lal, P. Smith, G. Tian, H. Tiessen, M. Van Noordwijk and P. L. Woomer, "Agricultural Sols as a Sink to Mitigate $\mathrm{CO}_{2}$ Emissions," Soil Use and Management, Vol. 13, No. 4, 1997, pp. 230244.

[9] G. Marland, R. Andres, T. A. Boden, C. Johnston and A. Brenkert, "Global, Regional and National $\mathrm{CO}_{2}$ Emission Estimates from Fossil Fuel Burning, Cement Production and Gas Flaring: 1751-1996," Report NDP-030, Carbon Dioxide Information Analysis Center, Oakridge National Laboratory, Oakridge, 1999.

[10] IPCC, "Land Use, Land Use Change and Forestry," Intergovernmental Panel on Climate Change, Cambridge University Press, Cambridge, 2000.

[11] R. A. Housghton, "The Annual Net Flux of Carbon to the Atmosphere from Changes in Land Use 1850 to 1990," Tellus B, Vol. 51, No. 2, 1999, pp. 298-313.

[12] L. Olsson and J. Ardö, "Soil Carbon Sequestration in Degraded Semiarid Agro-Ecosystems-Perils and Potentials," Ambio, Vol. 31, No. 6, 2002, pp. 471-477.

[13] D. Turner, W. K. Ferrel and M. E. Harmon, "The Carbon Crop," Nature, Vol. 277, No. 5332, 1997, pp. 1589-1590.

[14] M. E. Harmon, J. M. Harmon, W. K. Ferell and D. Brooks, "Modeling Carbon Stores in Oregon and Washington Forest Products: 1900-1992," Climatic Change, Vol. 33, No. 4, 1996, pp. 521-550.

[15] R. Lal, J. Kimble, R. F. Follet and B. A. Stewart, (Eds.) "Management of Carbon Sequestration in Soil," CRC, Boca Raton, 1998.

[16] M. Bernoux, C. C. Cerri, C. E. P. Cerri, M. S. Neto, A. Metay, A. S. Perrin, E. Scopel, T. Razafimbelo, D. Blavet, M. de C. Piccolo, M. Pavei and E. Milne, "Cropping Systems, Carbon Sequestration and Erosion in Brazil, a Review," Agronomy of Sustainable Development, Vol. 26, No. 1, 2006, pp. 1-8.

[17] R. Lal, "World Cropland Soils as a Source or Sink for Atmospheric Carbon," Advances in Agronomy, Vol. 71, 2000, pp. 145-191. 
[18] J. Dumanski and R. Lal, "Soil Conservation and the Kyoto Protocol Facts and Figures (Theme Paper)," Agriculture and the Environment, Environment Bureau, Agriculture and Agri-Food Canada, Ottawa, 2004.

[19] S. Kuo and E. Jellum, "Influence of Winter Cover Crop and Residue Management on Soil Nitrogen Availability and Corn," Agronomy Journal, Vol. 94, No. 3, 2002, pp. 501-508.

[20] R. P. Zentner, C. A. Campbell, V. O. Biederebeck, P. R. Miller, F. Selles and M. R. Fernandez, "In Search of a Suitable Cropping System for the Semi-Arid Canadian Prairies," Journal of Sustainable Agriculture, Vol. 18, No. 2-3, 2001, pp. 117-136.

[21] R. P. Zentner, C. A. Campbell, V. O. Biederebeck, F. Selles, R. Lemke, P. G. Jefferson and Y. Gan, "LongTerm Assessment of Management of an Annual Legume Green Manure Crop for Fallow Replacement in the Brown Soil Zone," Canadian Journal of Plant Science, Vol. 83, 2004, pp. 475-482.

[22] J. Dumanski, R. L. Desjardins, C. Tarnocai, C. Moreal, E. G. Gregorich, V. Kirkwood and C. A. Campbell, "Possibilities for Future Carbon Sequestration in Canadian Agriculture in Relation to Land Use Changes," Journal of Climate Research, Vol. 40, No. 1, 1998, pp. 81-103.

[23] L. E. Drinkwater, P. Wagoner and M. Sarrantonlo, "LegumeBased Cropping Systems have Reduced Carbon and Nitrogen Losses," Nature, Vol. 396, No. 6708, 1998, pp. 262-265.

[24] G. Marland and T. A. Boden, "Trends: A Compendium of Data on Global Change," Carbon Dioxide Information Analysis Center, Oak Ridge National Laboratory, Roane County, Tennessee, 1997.

[25] R. W. Willy, "Intercropping Studies with Annual Crops," In: J. Nugent and M. O'Connor, Eds., Better Crops for Food, CIBA Foundation Symposium 97, Pitman, London, 1983.

[26] R. Francis and D. R. Decoteau, "Developing an Effective Southernpea and Sweet Corn Intercrop System," Horticulture Technology, Vol. 3, No. 2, 1993, pp. 178-184.

[27] Anon, "Strip Intercropping Offers Low-Input Way to Boost Yields," Sensible Agriculture, Mono Publication, May 1990, pp. 7-8.

[28] P. Sullivan, "Intercropping Principles and Production Practices, Agronomy Systems Guide," Appropriate Technology Transfer for Rural Areas, 2003. http: //www.attra.ncat.org

[29] M. S. Wolf, "Crop Strength through Diversity," Nature, Vol. 406, August 2000, pp. 681-682.

[30] K. K. Hirst, "Mixed Cropping, Agricultural Technique Known as Mixed Cropping," 2009. http://archaeology. about.com/od/historyofagriculture/qt/mixed_cropping.ht $\mathrm{ml}$ (access date: 3/28/2010).

[31] Anon, "Mixed Cropping," http://simple.wikipedia.org/ wiki/Mixed_cropping.html

[32] M. Horrocks, P. A. Shane, I. G. Barber, D. M. D'Costa and S. L. Nichol, "Microbotanical Remains Reveal Poly- nesian Agriculture and Mixed Cropping in Early New Zealand," Review of Palaeobotany and Palynology, Vol. 131, No. 3-4, 2004, pp. 147-157.

[33] M. R. Jahansooz, I. A. M. Yunusa, D. R. Coventry, A. R. Palmer and D. Eamus, "Radiation- and Water-Use Associated with Growth and Yields of Wheat and Chickpea in Sole and Mixed Crops," European Journal of Agronomy, Vol. 26, No. 3, 2007, pp. 275-282.

[34] A. Gunes, A. Inal, M. S. Adak, M. Alpasian, E. G. Bagci, T. Erol and D. J. Pilbeam, "Mineral Nutrition of Wheat, Chickpea and Lentil as Affected by Mixed Cropping and Soil Moisture," Nutrient Cycling in Agroecosystems, Vol. 78, No. 1, 2007, pp. 83-96.

[35] S. Sahile, C. Fininsa, P. K. Sakhuja and S. Ahmed, "Effect of Mixed Cropping and Fungicides on Chocolate Spot (Botrytis Fabae) of Faba Bean (Vicia Faba) in Ethiopia," Crop Protection, Vol. 27, No. 2, 2008, pp. 275-282.

[36] S. C. Prochaska, "Three-Year Summary of Effect of Modified Relay Intercropping on Wheat Yield in 15-Inch Rows," In: P. Rzewnicki, Ed., Agronomic Crops Team on-Farm Research Projects, 2002. Special Circular 190. Wooster, Ohio Agricultural Research and Development Center, The Ohio State University, 2003.

[37] U. M. Sainju, B. P. Singh, F. W. Wayne and S. Wang, "Carbon Supply and Storage in Tilled and Nontilled Soils as Influenced by Cover Crops and Nitrogen Fertilization," Journal of Environmental Quality, Vol. 35, No. 4, 2006, pp. 1507-1517.

[38] Q. Wang, Y. Li and W. Klassen, "Influence of Summer Cover Crops on Retention of Soil Nitrogen and Phosphorus in a Subtropical Area," Journal of Soil and Water Conservation, Vol. 60, No. 1, 2005, pp. 58-63.

[39] Q. Wang, W. Klassen, Y. Li and M. Codallo, "Influence of Cover Crops and Irrigation Rates on Tomato Yields and Quality in a Subtropical Region," HortScience, Vol. 40, No. 7, 2005, pp. 2125-2131.

[40] G. Kuepper and M. Dodson, "Companion Planting: Basic Concepts and Resources," Horticulture Technical Note. http://www.attra.ncat.org

[41] J. Boucher, "Setting a Trap," American Vegetable Grower, January 2000, pp. 20-22.

[42] G. E. Rodolfo and D. L. Plucknett, "Ratoon Cropping of Sorghum: II. Effect of Day Length and Temperature on Tillering and Plant Development," Journal series No. 1775, Hawaii Agricultural Station, University of Hawaii, Honolulu, 1975.

[43] Y. Li, W. Klassen, M. Lamberts and T. Olczyk, "Okra Production in Miami-Dade County, Florida," HS-875, 2006. http://edis.ifas.ufl.edu

[44] K. K. McLauchlan and S. E. Hobbie, "Comparison of Labile Soil Organic Matter Fractionation Techniques," Soil Science Society of American Journal, Vol. 68, No. 2, 2004, pp. 1616-1625.

[45] L. Janik, L. Spouncer, R. Correl and J. Skjemstad, "Sensitivity Analysis of the Roth-C Soil Carbon Model," National Carbon Accounting System Technical Report No. 
30, CSIRO Land and Water and Mathematical and Information Sciences, Australian Greenhouse Office, 2002.

[46] U. M. Sainju, B. P. Singh and W. F. Whitehead, "Long-Term Effects of Tillage, Cover Crops, and Nitrogen Fertilization on Organic Carbon and Nitrogen Concentrations in Sandy Loam Soils in Georgia, USA," Soil Tillage Research, Vol. 63, No. 3-4, 2002, pp. 167-179.

[47] U. M. Sainju, W. F. Whitehead and B. P. Singh, "Agricultural Management Practices to Sustain Crop Yields and Improve Sol and Environmental Qualities," The Sci-

Unit conversion:

$\mathrm{Mg}($ megagram $)=1 \times 10^{6} \mathrm{~g}$ or million gram;

$\mathrm{Gg}($ gigagram $)=1 \times 10^{9} \mathrm{~g}$ or billion gram;

$\operatorname{Tg}($ teragram $)=1 \times 10^{12} \mathrm{~g}$ or trillion gram or million ton;

$\mathrm{Pg}($ petagram $)=1 \times 10^{15} \mathrm{~g}$ or billion ton; ppmv (parts per million by volume $)=1 \times 10^{-6}$ liter;

ppbv (parts per billion by volume) $=1 \times 10^{-9}$ liter;

pptv (parts per trillion by volume $)=1 \times 10^{-12}$ liter. ence World, Vol. 3, 2003, pp. 768-789.

[48] U. M. Sainju, W. F. Whitehead and B. P. Singh, "Carbon Accumulation in Cotton, Sorghum, and Underlying Soil as Influenced by Tillage, Cover Crops, and Nitrogen Fertilization," Plant and Soil, Vol. 273, No. 1-2, 2005, pp. 219-234.

[49] T. O. West and W. M. Post, "Soil Organic Carbon Sequestration Rates by Tillage and Crop Rotation: A Global Data Analysis," Soil Science Society of American Journal, Vol. 66, No. 6, 2002, pp. 1930-1946. 